\title{
HUBUNGAN ANTARA PERILAKU BELAJAR DENGAN HASIL BELAJAR PESERTA DIDIK PADA MATA PELAJARAN AQIDAH AKHLAK DI PESANTREN AL-URWATUL WUTSQAA BENTENG SIDRAP
}

\author{
Nurfadhilah \\ Ummu Kalsum Yunus \\ Fakultas Tarbiyah \& Keguruan \\ UIN Alauddin Makassar
}

\begin{abstract}
Abstrak: The purpose of this study, namely: 1) Describe the learning behavior in Pesantren Al-Urwatul Wutsqaa Fort Sidrap. 2) Describe the learning outcomes of learners on the Subject of Aqidah Akhlak in Pesantren Al-Urwatul Wutsqaa Fort Sidrap. 3) Knowing the behavior of learning with learners' learning outcomes on Subjects Aqidah Akhlak in Pesantren Al-Urwatul Wutsqaa Fort Sidrap.

This thesis uses 205 pupolation that is all students class VIII MTs Al-Urwatul Wutsqaa Fort Sidrap and sample of 31 learners. The research instrument used is observation and note format. Data analysis technique used is quantitative descriptive analysis technique and using product moment.

The average learning behavior of learners on subjects Aqidah Akhlak 84.3 lies in the interval of 81-100, which is in very good category. The average Learning Outcome of the learner is 72.5 which lies at intervals of 61-80, which are in either category. Learning behavior does not affect the students learning outcomes on subjects Aqidah Akhlak in Pesantren Al-Urwatul Wutsqaa Fort Sidrap. Hasil test $t O=0.81<$ from $t t=1.699$. So it can be said that $H O$ accepted and $\mathrm{Ha}$ rejected, meaning there is no relationship between learning behavior with learners' learning outcomes in the eyes of the Aqidah of Morals in Pesantren Al-Urwatul Wutsqaa Fort Sidrap.
\end{abstract}

Keywords: Learning Behavior, Education, Aqidah Akhlak

\section{PENDAHULUAN}

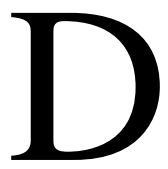
alam arti sederhana pendidikan sering diartikan sebagai usaha manusia untuk membina kepribadiannya sesuai dengan nilai-nilai di dalam masyarakat dan kebudayaan. Dalam perkembangannya, istilah pendidikan atau paedagogie berarti bimbingan atau pertolongan yang diberikan dengan sengaja oleh orang dewasa agar ia menjadi dewasa. ${ }^{1}$ Dalam Undang-Undang RI. Nomor 20 Tahun 2003 dijelaskan bahwa:

Pendidikan adalah usaha sadar dan terencana untuk mewujudkan suasana belajar

\footnotetext{
${ }^{1}$ Hasbullah, Dasar-Dasar Ilmu Pendidikan (Cet. X; Jakarta: PT Raja Grafindo Persada, 2012), h.1.
} 
dan proses pembelajaran agar peserta didik secara aktif mengembangkan potensidirinya untuk memiliki kekuatan spiritual keamanan, pengendalian diri,kepribadian, kecerdasan, akhlak mulia, serta keterampilan yang diperlukan dirinya, masyarakat, bangsa, dan Negara. $^{2}$

Pendidikan Islam berasal dari kata tarbiyah, ta'lim, dan ta'dib. Tabiyah dengan kata kerja "rabba" kata "pengajaran" dalam bahsa Arabnya adalah "ta'lim" dengan kata kerjanya "allam". Pendidikan dan pengajaran dalam bahasa arabnya "tarbiyah wa ta'lim sedangkan pendidikan islam dalam bahasa Arabnya adalah "Tarbiyah Islamiyah". Sementara "ta'lim" dengan kata kerjanya "allama" juga sudah digunakan pada zaman Nabi. Baik dalam Al-qur'an, hadist atau pemakaian sehari-hari, kata ini lebih banyak digunakan daripada kata "tarbiyah", dan "ta'dib" kata lain yang mengandung arti pendidikan itu ialah "addaba" dengan demikian ketiga kata tersebut pada dasarnya mengacu kepada pembinaan, pimpinan, pemeliharaan dan sebagainya. ${ }^{3}$

Secara khusus pendidikan agama merupakan bagian pendidikan yang sangat penting yang berkenaan dengan aspek-aspek sikap dan nilai, antara lain akhlak, keagamaan dan sosial masyarakat. ${ }^{4}$

Islam adalah agama Allah yang diwahyukan kepada Nabi Muhammad saw dan ia adalah agama yang berintikan keimanan dan perbuatan (amal) keimanan itu merupakan akidah dari pokok itu dikeluarkan cabang-cabangnya. ${ }^{5}$ Akhlak merupakan aspek sikap hidup atau kepribadian hidup manusia, dalam arti bagaimana sistem norma yang mengatur hubungan manusia dengan Allah (ibadah dalam arti khas) dan hubungan manusia dengan manusia lainnya(muamalah) itu terjadi sikap hidup dan kepribadian hidup manusia dalam menjalankan sistem kehidupannya (politik, ekonomi, sosial, pendidikan, kekeluargaan, kebudayaan/seni, iptek, olaraga/kesehatan, dan lain-lain) yang dilandasi oleh aqidah yang kokoh.

Dengan demikian, aqidah akhlak yang merupakan salah satu sub mata pelajaran pendidikan agama Islam di Sekolah mengandung Pengertian: pengetahuan, pemahaman, dan penghayatan tentang keyakinan atau kepercayaan (iman) dalam Islam menetap dan melekat dalam hati yang berfungsi sebagai pandangan hidup, perkataan dan amal perbuatan sisawa dalam segala aspek kehidupannya sehari-hari.

Hasil belajar pada mata pelajaran Aqidah Akhlak tentunya dapat membentuk perilaku ihsan dilingkungan sekolah maupun lingkungan rumah, sebab perilaku yang baik

2 Departemen Pendidikan Nasional RI UUD No. 20 Tahun 2003 (Jakarta: Biro Hukum dan Sekretariat Jenderal Departemen Pendidikan Nasional, 2003), h.8.

${ }^{3}$ Proyek Pembinaan Perguruan Tinggi Agama Islam, Ilmu Pendidikan Islam(Jakarta: Perpustakaan Pusat I.A.IN.1984), H. 25.

${ }^{4}$ Muhaimin, Wacana Pengembangan Pendidikan Islam (Cet. I; Yogyakarta: Pustaka Pelajar, 2003), h, 308 .

${ }^{5}$ Sayid Sabiq, Aqidah Ahklak Islam Pola Hidup Manusia Beriman (Bandung: C.V Diponegoro, 1978), h. 15. 
akan menuntun pelakunya kedalam perbuatan yang ma'ruf, serta dapat membedakan mana yang haq dan yang batil. Secara teoritis, peserta didik yang memiliki nilai aqidah akhlak yang tinggi akan memiliki perilaku yang baik, tetapi kondisi tersebut terkadang tidak sesuai dengan yang kita lihat. Karna tidak selamanya perilaku belajar peserta didik dapat berpengaruh pada hasil belajar yang memuaskan, terkadang ada peserta didik yang perilaku belajarnya dalam kelas sangat baik akan tetapi hasil belajarnya tidak memuaskan. Itu terjadi karna salah satu penyebabnya adalah peserta didik tersebut lambat menangkap pelajaran, tapi ada juga peserta didik yang didalam kelas perilaku belajarnya kurang baik akan tetapi hasil belajarnya sangat memuskan. Itu terjadi karena salah satu penyebabnya adalah peserta didik tersebut cepat menangkap pelajaran. Tetapi tidak selamanya peserta didik seperti itu, karena terkadang juga ada peserta didik yang baik perilaku belajarnya baik pula hasil belajarnya begitupun sebaliknya. Sejalan dengan itu, untuk melihat kemungkinan yang terjadi tentang "hubungan antara perilaku belajar dengan hasil belajar peserta didik pada mata pelajaran aqidah akhlak di Pesantren AlUrwatul Wutsqaa Benteng Sidrap perlu diadakan suatu penelitian.”

Hipotesis Penelitian yang diajukan oleh penulis adalah "Terdapat Hubungan Positif dan Signifikan antara Perilaku Belajar dengan Hasil Belajar Peserta Didik Pada Mata Pelajaran Aqidah Akhlak di Pesantren Al-Urwatul Wustqaa Benteng Sidrap”.

Hipotesis statistic dalam penelitian ini adalah sebagai berikut:

$\mathrm{H}_{0}: \rho=0$

$\mathrm{H}_{\mathrm{a}}: \rho \neq 0^{6}$

$\mathrm{H}_{\mathrm{o}}$ : Tidak terdapat pengaruh yang positif dan signifikan antara perilaku belajar dengan hasil belajar peserta didik pada mata pelajaran Aqidah Akhlak di Pesantren Al-Urwatul Wutsqaa Benteng Sidrap.

$\mathrm{H}_{\mathrm{a}}$ : Terdapat pengaruh yang positif dan signifikan antara perilaku belajar dengan hasil belajar peserta didik pada mata pelajaran Aqidah Akhlak di Pesantren AlUrwatul Wutsqaa Benteng Sidrap.

\section{TINJAUAN TEORITIS}

Perilaku dalam bahasa Inggris disebut dengan 'behavior' yang berarti kelakuan, tindak-tanduk jalan. ${ }^{7}$ Perilaku juga terdiri dari dua kata peri dan laku, peri yang berarti sekeliling, dekat, melingkupi. Dan laku artinya tingkah laku, perbuatan, tindak tanduk. ${ }^{8}$

Kata perilaku mempunyai pengertian yang sangat luas, yaitu tidak hanya mencakup kegiatan yang motorik saja, seperti; berjalan, berlari-lari, berolah raga, bergerak dan lainlain. Akan tetapi juga membahas macam-macam fungsi seperti: melihat, mendengar,

\footnotetext{
${ }^{6}$ Sugiyono, Statistika untuk Penelitian (Bandung: Alfabeta, 2014), h. 89.

${ }^{7}$ Jhon M, Echol, et al., Kamus Inggris Indonesia (Cet. XIII; Jakarta: PT. Gramedia, 1996), h, 80.

${ }^{8}$ Pedoman Umum Bahasa Indonesia Yang Disempurnahkan (Cet. V; Bandung: CV. Pustaka Setia,
} 1996), h, 91. 
mengingat, berfikir, fantasi, pengenalan kembali, penampilan emosi dalam bentuk tangis atau senyum dan sebagainya. ${ }^{9}$

Belajar dari kata ajar yang berarti petunjuk yang diberikan kepada orng supaya diketahui (dituntut) oleh orang lain. ${ }^{10}$ Sedangkan Slameto mengungkapkan bahwa belajar adalah suatu proses usaha yang dilakukan seseornag untuk memperoleh suatu perubahan tingkah laku yang baru secara keseluruhan sebagai hasil pengalamannya sendiri dalam interaksi dengan lingkungannya. ${ }^{11}$

Belajar adalah proses untuk membuat perubahan dalam diri peserta didik dengan cara berinteraksi dengan lingkungan untuk mendapatkan perubahan dalam aspek kognitif, afektif dan psikomotorik. Pada teori belajar perilaku, proses belajar cukup dilakukan dengan mengikatkan antara stimulus dan respons secara berulang, sedang pada teori kognitif, proses belajar membutuhkan pengertian dan pemahaman. ${ }^{12}$

Dikemukakan empat jenis teori belajar, berdasarkan aliran-aliran psikologi yang ada yaitu:

a) Teori Behaviorisme

Behaviorisme merupakan aliran psikologi yang memandang individu hanya dari sisi fenomena jasmaniah, dan mengabaikan aspek-aspek mental. Dengan kata lain, behavoirisme tidak mengakui adanya kecerdasan, bakat, minat dan perasaan individu dalam suatu belajar. Peristiwa belajar semata-mata melatih reflex-refleks sedemikian rupa sehingga menjadi kebiasaan yang dikuasai individu.

b) Teori Belajar Kognitif

Piaget merupakan salah seorng tokoh yang disebut-sebut sebagai pelopor aliran konoopostruktivisme. Salah satu sumbangan pemikirannya yang banyak digunakan sebagai rujukan utnuk memahami perkembangan individu. Menurut Piaget bahwa perkembangan kognitif individu meliputi empat tahap yaitu:

(1) Sensor motorik

(2) Pra operasional

(3) Operasional konkret

(4) Operasional formal

Belajar akan lebih berhasil apabila disesuaikan dengan tahap perkembangan kognitifpeserta didik. Peserta didik hendaknya diberi kesempatan untuk melakukan eksperimen dengan obyek fisik, yaitu di tunjang oleh interaksi dengan teman sebaya dan dibantu oleh pertanyaan dari guru. Guru hendaknya banyak memberikan rangsangan

${ }^{9}$ Mahfudh Shalahuddin, Pengantar Psikologi Umum (Surabaya: Sinar Wijaya, 1991), h, 55.

${ }^{10}$ Tim Penyusun. Kamus Besar Bahasa Indonesia. (Cet. II; Jakarta: Balai Pustaka, 1992), h. 13.

${ }^{11}$ Slameto, Belajar dan Faktor-Faktor yang Mempengaruhinya (Jakarta: PT. Raja Grafindo Persada, 1003), h. 215.

${ }^{12}$ Dr. Purwanto, M.Pd, Evaluasi Hasil Belajar (Cet. III; Yogyakarta: Celeban Timur UH III/548, 2011), h. 43. 
kepada peserta didik agar mau berinteraksi dengan lingkungan secara aktif, mencari dan menemukan berbagai hal dari lingkungan.

c) Teori Pemrosesan Informasi Belajar

Asumsi yang mendasari teori ini adalah bahwa pembelajaran merupakan faktor yang sangat penting dalam perkembangan. Perkembangan merupakan hasil kumulatif dari pembelajaran. Menurut Gagne bahwa dalam pembelajaran terjadi proses penerimaan informasi, untuk kemudian diolah sehingga menghasilkan keluaran dalam bentuk hasil belajar.

Dalam pemrosesan informasi terjadi adanya interaksi antara kondisi-kondisi internal dan kondisi-kondisi ekstrenal individu. Kondisi internal yaitu keadaan dalam diri individu yang diperlukan untuk mencapai hasil belajar dan proses kognitif yang terjadi dalam individu. Sedangkan kondisi eksternal adalah rangsangan dari lingkunagan yang mempengaruhi individu dalam proses pembelajaran.

d) Teori Belajar Gestalt

Gestalt berasal dari bahasa Jerman yang mempunyai arti sebagai "bentuk atau konfigurasi”. Pokok pandangan Gestalt adalah bahwa obyek atau peristiwa tertentu akan dipandang sebagai sesuatu keseluruhan yang terorganisasikan. ${ }^{13}$

Adapun faktor-faktor yang mempengaruhi perilaku, yaitu:

a) Faktor internal peserta didik

(1) Fisiologis

Yang menandai tingkat kebugaran organ-organ tubuh dan sendi-sendinya, dapat mempengaruhi semangat dan intesitas dalam mengikuti pelajaran. Kondisi organ-organ tubuh yang lemah, apalagi disertai pusing-pusing kepala misalnya, dapat menurunkan kualitas rana cipta (kognitif) sehingga materi yang dipelajarinya pun kurang atau tidak berbekas.

(2) Psikologis

(a) Intelegensi

Intelegensi dapat diartikan sebagai kemampuan psiko- fisik untuk mereaksi rangsangan atau menyesuaikan diri dengan lingkungan dengan cara yang tepat.

(b) Sikap

Sikap adalah gejala internal yang berdimensi afektif yang berupa kecenderungan untuk mereaksi atau merespon dengan cara yang relatif tetap terhadap obyek orang, barang, dan sebagainya, baik secara positif maupun negatif.

(c) Bakat

${ }^{13}$ Ratna Yudhawati, dkk. Teori-Teori Psikologi Pendidikan (Cet. I; Jakarta: PT Prestasi Pustakaraya, 2011), h. 41-47. 
Secara umum bakat adalah kemampuan potensial yang dimiliki seseorang untuk mencapai keberhasilan pada masa yang akan datang. Dengan demikian, sebetulnya setiap orang pasti memiliki bakat dalam arti berpotensi untuk mencapai prestasi sampai ketingkat tertentu sesuai dengan kapasitas masing-masing. Jadi secara global bakat itu mirip dengan intelegensi.

(d) Minat

Minat berarti kecenderungan dan kegairahan yang tinggi atau keinginan yang besar terhadap sesuatu.

(e) Motivasi

Motivasi adalah keadaan internal organisme baik manusia maupun hewan yang mendorongnya berbuat sesuatu. Dalam pengertian ini, motivasi berarti pemasok daya (energizer) untuk bertingkah laku secara terarah.

b) Faktor eksternal

(1) Lingkungan sosial

Lingkungan sosial sekolah seperti guru dan teman kelas, yang dapat mempengaruhi semngat belajar seorang peserta didik sehingga menjadi daya dorong yang positif bagi kegiatan belajar peserta didik. Lingkungan sosial yang lebih banyak memepengaruhi kegiatan belajar ialah orang tua dan peserta didik itu sendiri, karna sifat-sifat dan pengelolaan keluarga semuanya dapat memberi dampak baik dan buruk terhadap kegiatan belajar dan hasil yang dicapai nantinya.

(2) Lingkungan Non-sosial

Yang termasuk disini adalah gedung sekolah dan letaknya, rumah tempat tinggal keluarga dan letaknya, alat-alat belajar, keadaan cuaca, dan waktu belajar yang digunakan peserta didik. Faktor-faktor ini dipandang turut menentukan tingkat keberhasilan belajar peserta didik. ${ }^{14}$

Tujuan pendidikan direncanakan untuk dapat dicapai dalam proses belajar mengajar. Hasil belajar merupakan pencapaian tujuan pendidikan pada peserta didik yang mengikuti proses belajar mengajar. Tujuan pendidikan bersifat ideal, sedang hasil belajar bersifat aktual. Hasil belajar merupakan realisasi tercapainya tujuan pendidikan, sehingga hasil belajar yang diukur sangat tergantung krpada tujuan pendidikannya.

Hasil belajar perlu dievaluasi. Evaluasi dimaksudkan sebagai hasil belajar cermin utnuk melihat kembali apakah tujuan yang ditetapkan telah tercapai dan apakah proses belajar mengajar telah berlangsung efektif untuk memperoleh hasil belajar. ${ }^{15}$

\footnotetext{
${ }^{14}$ Syah Muhaibbin, Psikologi Pendidikan dengan Pendekatan Baru. (Bandung: PT Remaja Rosdakarya,2005), h. 132.

${ }^{15}$ Dr. Purwanto, M.Pd, Evaluasi Hasil Belajar (Cet. III; Yogyakarta: Celeban Timur UH III/548, 2011), h. 46.
} 
Hasil belajar merupakan indikator keberhasilan yang dicapai peserta didik dalam usaha belajarnya. Hasil belajar adalah istilah yang digunakan untuk menyatakan tingkat keberhasilan yang dicapai seseorang melalui proses belajar. Hasil belajar adalah kemampuan-kemampuan yang dimiliki peserta didik setelah ia menerima pengalaman belajarnya. ${ }^{16}$

Menurut Bloom bentuk perilaku atau hasil belajar sebagai tujuan yang harus dirumuskan dapat digolongkan ke dalam tiga klasifikasi/ranah yakni;

a) Ranah Kognitif

Ranah kognitif merupakan tujuan pembelajaran yang berhubungan dengan kemampuan intelektual atau kemampuan berfikir, seperti kemampuan mengingat dan kemampuan memecahkan masalah. Ranah kognitif menurut Bloom terdiri dari enam tingkatan, yaitu:

(1) Pengetahuan

(2) Pemahaman

(3) Penerapan

(4) Analisis

(5) Sintesis

(6) Evaluasi

b) Ranah afektif

Ranah afektif berkenaan dngan sikap, nilai-nilai dan apresiasi. Ranah ini merupakan bidang tujuan pendidikan kelanjutan kelanjutan dari ranah kognitif. Artinya seseorang hanya akan memiliki sikap tertentu terhadap suatu objek manakala telah memiliki kemampuan kognitif tingkat tinggi.

c) Ranah psikomotorik

Ranah psikomotorik adalah tujuan yang berhubungan dengan kemampuan keterampilan atau skill seseorang. Ranah psikomotorik meliputi semua tingkah laku yang menggunakan syaraf dan otot badan. Aspek ini sering berhubungan dengan bidang studi yang lebih banyak menekankan kepada gerakan-gerakan atau keterampilan, misalnya seni lukis, musik, pendidikan jasmani dan olahraga. ${ }^{17}$

Faktor-faktor yang mempengaruhi hasil belajar banyak jenisnya, tetapi dapat digolongkan menjadi dua golongan saja yakni faktor intern (dari peserta didik itu sendiri) dan faktor ekstern (dari luar diri peserta didik).

a) Faktor Internal

Yang ter masuk faktor internal adalah :

\footnotetext{
${ }^{16}$ Nana Sudjana, Penilaian Hasil Proses Belajar Mengajar (Bandung: Rosda Karya. 2005), h. 22.

${ }^{17}$ Sanjaya, Wina, Perencanaan dan Desain Sistem Pembelajaran, (Jakarta: Kencana Prenada Media Group, 2011), h, 125.
} 
1) Faktor jasmani (fisiologi) baik yang bersifat bawaan maupun yang diperoleh. Yang termasuk ini misalnya penglihatan, pendengaran, struktur tubuh dan sebagainya. ${ }^{18}$

2) Faktor psikologi, yang termasuk faktor psikologi yang mempengaruhi belajar yaitu intelegensia, perhatian, minat, motivasi, dan kematangan. ${ }^{19}$

Faktor-faktor di atas dapat diuaraikan sebagai berikut :

(f) Intelegensi

Intelegensi adalah kecakapan yang terdiri dari tiga jenis yaitu kecakapan untuk menghadapi dan menyesuaikan ke dalam situasi yang baru dengan cepat dan efektif, mengetahui/menggunakan konsep-konsep yang abstrak secara efektif, dan mengetahui relasi dan mempelajarinya dengan cepat.

(g) Perhatian

Perhatian menurut Gazali yang dikutip Slameto adalah : keaktifan jiwa yang dipertinggi, jiwa itu pun semata-mata tertuju kepada suatu obyek (benda/hal) atau sekumpulan objek. Untuk dapat menjamin hasil belajar yang baik, maka peserta didik harus mempunyai perhatian terhadap bahan yang dipelajarinya, jika bahan pelajaran tidak menjadi perhatian peserta didik, maka timbullah kebosanan pada peserta didik sehingga ia tidak suka belajar, olehnya itu dalam belajar, usahakan bahan pelajaran selalu menarik dan sesuai dengan mutu atau bakat peserta didik sehingga peserta didik tidak bosan.

(h) Minat peserta didik

Secara sederhana minat (interest) berarti kecenderungan dan kagairahan yang tinggi atau yang besar terhadap sesuatu, minat ini sangat berpengaruh dalam belajar. Karena seorang peserta didik yang menaruh minat besar terhadap mata pelajaran tertentu, maka dia akan memusatkan perhatiannya secara intensif terhadap materi itu, sehingga memungkinkan untuk belajar lebih giat lagi.

(i) Motivasi

Pengertian dasar motivasi adalah keadaan internal organisme, baik manusia ataupun hewan-hewan yang mendorongnya untuk berbuat sesuatu dalam pengertian ini motivasi berarti pemasukan daya (energizer) untuk bertingkah laku secara terarah.Motivasi instrinsik adalah hal dan keadaan yang berasal dari dalam diri peserta didik sendiri yang dapat mendorongnya melakukan tindakan dari luar individu peserta didik yang juga mendorongnya untuk melakukan kegiatan belajar.

(j) Kematangan

Kematangan adalah suatu tingkat/fase dalam pertumbuhan seseorang, dimana alat-alat tubuhnya siap untuk melaksanakan kecakapan baru.

\footnotetext{
${ }^{18}$ Abu Ahmadi, Widodo Supriyono, Psikologi Belajar (Cet. I; Jakarta: Rineka Cipta. 1991), h. 130.

${ }^{19}$ Slameto, Belajar dan Faktor-faktor yang Mempengaruhinya (Cet.IV; Jakarta: PT. Rineka Cipta. 2003), h.54.
} 
b) Faktor Eksternal

1) Faktor keluarga; peserta didik yang belajar akan menerima pengaruh dari keluarga berupa cara orang tua mendidik, relasi antara anggota keluarga, suasana rumah tangga dan keadaan ekonomi keluarga. ${ }^{20}$

Faktor-faktor di atas dapat di uraikan sebagai berikut:

(a) Cara Orang Tua Mendidik

Kemauan anak untuk belajar tidak terlepas dari bagaimana cara orang tua mendidiknya. Sebab keluarga sebagai lembaga pendidikan yang pertama dan utama sangat memegang peranan penting.Dapatlah dipahami betapa pentingnya peranan kelurga dalam pendidikan anaknya. Karena cara orang tua mendidik anak-anak akan berpengaruh terhadap belajarnya.

(b) Relasi antara Anggota Keluarga

Relasi antara anggota keluarga yang terpenting adalah relasi orang tua dengan anaknya.Hubungan ini harus diciptakan dengan suasana yang harmonis, penuh perhatian dan kasih sayang di antara semua anggota keluarga.Karena baik tidaknya hubungan dalam keluarga sangat menentukan kesuksesan belajar anak itu sendiri.

(c) Suasana Rumah Tangga dan Keadaan Ekonomi Keluarga

Selain faktor yang telah disebutkan sebelumnya di atas suasana rumah tangga yang sudah gaduh ataupun tenang dan lain-lain sangat mempengaruhi ketenangan anak untuk belajar. Olehnya itu perlu diciptakan suasana rumah yang tenang dan harmonis, sehingga anak dapat tenang belajar dan kerasan tinggal di rumah.

Kondisi ekonomi keluarga juga merupakan faktor yang mempengaruhi keberhasilan belajar anak, hal ini erat kaitannya dengan fasilitas-fasilitas yang diperlukan dalam belajar, dan fasilitas belajar ini akan terpenuhi jika didukung oleh ekonomi yang cukup.

2) Faktor sekolah; faktor sekolah yang mempengaruhi hasil belajar ini mencakup metode mengajar, relasi guru dengan peserta didik, relasi peserta didik dengan peserta didik, disiplin sekolah, pelajaran dan waktu sekolah, standar pelajaran, keadaan gedung, metode belajar dan tugas rumah. ${ }^{21}$

\footnotetext{
${ }^{20}$ Muhibbin Syah, Psikologi Pendidikan dengan Pendekatan baru (Cet. V; Bandung: Remaja Rosda Karya Offset, 2000), h, 136.

${ }^{21}$ Slameto, Belajar dan Faktor-faktor yang Mempengaruhinya, h. 64.
} 


\section{Kerangka Pikir}

Secara teoretis, peserta didik yang memiliki nilai Aqidah Akhlak yang

tinggi akan memiliki perilaku baik,

tetapi kondisi tersebut terkadang tidak

sesuai dengan yang kita lihat.

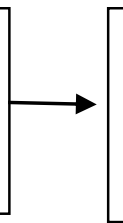

Hubungan antara perilaku belajar dengan hasil belajar peserta didik

pada mata pelajaran Aqidah Akhlak

peserta didik di Pesantren Al-

Urwatul Wutsqaa Benteng Sidrap.

Rumusan Masalah:

1. Bagaimana bentuk perilaku belajar peserta didik pada mata pelajaran Aqidah Akhlak di Pesantren Al-Urwatul Wutsqaa Benteng Sidrap.

2. Bagaimana derajat hasil belajar peserta didik pada mata pelajaran Aqidah Akhlak peserta didik di Pesantren AlUrwatul Wutsqaa Benteng Sidrap.

3. Apakah perilaku belajar berhubungan positif dan signifikan dengan hasil belajar peserta didik pada mata pelajaran Aqidah Akhlak peserta didik di Pesantren Al-Urwatul Wutsqaa Benteng Sidrap.

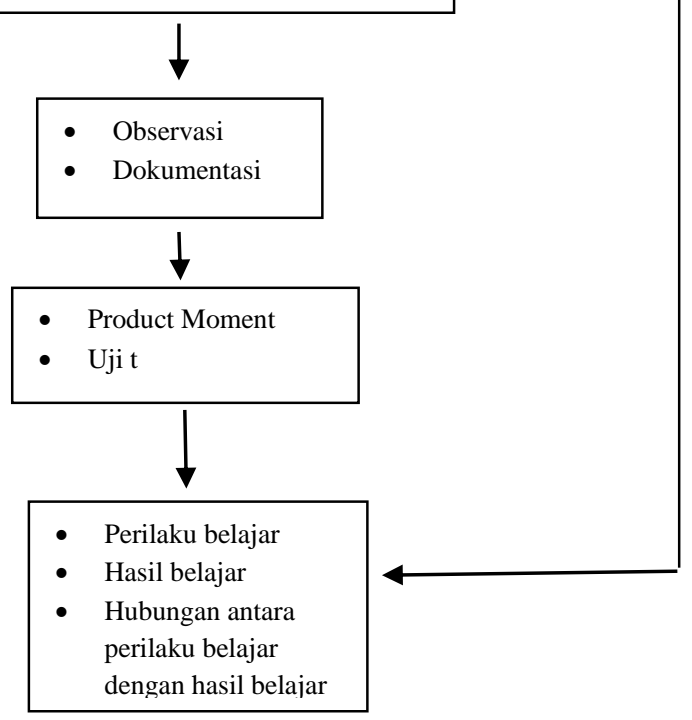

\section{METODE PENELITIAN}

Jenis penelitian yang digunakan yaitu penelitian kuantitatif. lokasi penelitian dalam penelitian ini yaitu Pesantren Al-Urwatul Wutsqaa Benteng Sidrap. Populasi Peserta Didik Pesantren Al-Urwatul Wutsqaa Tahun 2016

\begin{tabular}{|c|c|c|c|}
\hline Kelas & Laki-laki & Perempuan & Jumlah \\
\hline VIIIa & 34 & - & 34 \\
\hline VIIIb & 35 & - & 35 \\
\hline VIIIc & 33 & - & 33 \\
\hline VIIId & 27 & - & 27 \\
\hline VIIIe & - & 25 & 25 \\
\hline VIIIf & - & 27 & 27 \\
\hline VIIIg & - & 24 & 24 \\
\hline \multicolumn{3}{|l}{} & 205 \\
\hline
\end{tabular}


Penelitian ini, mengambil sampel dengan menggunakan teknik Simple random sampling akan mengambil sampel sebanyak $15 \%$ dari jumlah populasi yaitu 15/100 $\times$ $205=31$. Jadi dalam penelitian ini peneliti akan menentukan sampel dari 205 peserta didik dan mengambil sampel sebanyak 31 peserta didik.

\section{HASIL PENELITIAN}

\section{Deskripsi bentuk perilaku belajar peserta didik pada Mata Pelajaran Aqidah Akhlak di Pesantren Al-Urwatul Wutsqaa Benteng Sidrap}

Untuk mengetahui lebih jauh perilaku belajar peserta didik pada mata pelajaran Aqidah Akhlak di Pesantren Al-Urwatu Wutsqaa Benteng Sidrap. Maka peneliti menggunakan instrumen penelitian yaitu observasi. Dimana observasi ini bertujuan untuk mengetahui perilaku peserta didik ketika mengikuti pembelajaran terutama pelajaran Aqidah Akhlak. Adapun observasi yang dilakukan yaitu observasi secara individual terhadap peserta didik yang terpilih sebagai sampel dalam 1 kelas ketika pembelajaran Aqidah Akhlak sedang berlangsung. Untuk mengetahui lebih jelas mengenai perilaku belajar peserta didik maka peneliti mendiskripsikan hasil observasi per item pernyataan dalam bentuk tabel.

\section{Peserta didik membaca doa sebelum belajar}

\begin{tabular}{|c|c|c|c|}
\hline No & Jawaban Pernyataan & Frekuensi & Persentase \\
\hline 1 & Selalu & 28 & $90,3 \%$ \\
\hline 2 & Sering & 1 & $3,2 \%$ \\
\hline 3 & Jarang & 2 & $6,5 \%$ \\
\hline 4 & Sangat kurang & 0 & $0 \%$ \\
\hline & Jumlah & 31 & $100 \%$ \\
\hline
\end{tabular}

Hal ini dapat ditarik kesimpulan bahwa pada umumnya peserta didik selalu membaca doa sebelum belajar.

\section{Peserta didik menyiapkan perlengkapan belajar}

\begin{tabular}{|c|c|c|c|}
\hline No & Jawaban Pernyataan & Frekuensi & Persentase \\
\hline 1 & Selalu & 27 & $87 \%$ \\
\hline 2 & Sering & 3 & $10 \%$ \\
\hline 3 & Jarang & 0 & $0 \%$ \\
\hline 4 & Sangat Kurang & 1 & $3 \%$ \\
\hline & Jumlah & 31 & $100 \%$ \\
\hline
\end{tabular}

Hal ini dapat ditarik kesimpulan bahwa pada umumnya peserta didik selalu menyiapkan perlengkapan belajar.

3. Peserta didik datang sebelum pelajaran dimulai.

\begin{tabular}{|c|c|c|c|}
\hline No & Jawaban Pernyataan & Frekuensi & Persentase \\
\hline 1 & Selalu & 28 & $90,3 \%$ \\
\hline 2 & Sering & 1 & $3,2 \%$ \\
\hline 3 & Jarang & 2 & $6,5 \%$ \\
\hline
\end{tabular}




\begin{tabular}{|l|l|c|c|}
\hline 4 & Sangat Kurang & - & - \\
\hline \multicolumn{2}{|l|}{ Jumlah } & 31 & $100 \%$ \\
\hline
\end{tabular}

Hal ini dapat ditarik kesimpulan bahwa pada umumnya peserta didik selalu datang sebelum pelajaran dimulai.

4. Peserta didik memahami penjelasan pendidik tentang materi pembelajaran aqidah akhlak

\begin{tabular}{|c|c|c|c|}
\hline No & Jawaban Pernyataan & Frekuensi & Persentase \\
\hline 1 & Selalu & 28 & $90,3 \%$ \\
\hline 2 & Sering & - & - \\
\hline 3 & Jarang & 2 & $6,5 \%$ \\
\hline 4 & Sangat kurang & 1 & $3,2 \%$ \\
\hline \multicolumn{2}{|c|}{ Jumlah } & 31 & $100 \%$ \\
\hline
\end{tabular}

Hal ini dapat ditarik kesimpulan bahwa pada umumnya peserta didik selalu memahami penjelasan pendidik tentang teori pembelajaran Aqidah Akhlak.

\section{Peserta didik memperhatikan penjelasan pendidik}

\begin{tabular}{|c|c|c|c|}
\hline No & Jawaban Pernyataan & Frekuensi & Persentase \\
\hline 1 & Selalu & 28 & $90,3 \%$ \\
\hline 2 & Sering & 1 & $3,2 \%$ \\
\hline 3 & Jarang & - & - \\
\hline 4 & Sangat Kurang & 2 & $6,5 \%$ \\
\hline & Jumlah & 31 & $100 \%$ \\
\hline
\end{tabular}

Hal ini dapat ditarik kesimpulan bahwa pada umumnya peserta didik selalu memperhatikan penjelasan pendidik.

6. Peserta didik aktif berdiskusi dalam proses pembelajaran

\begin{tabular}{|c|c|c|c|}
\hline No & Jawaban Pernyataan & Frekuensi & Persentase \\
\hline 1 & Selalu & 27 & $87 \%$ \\
\hline 2 & Sering & 3 & $10 \%$ \\
\hline 3 & Jarang & 0 & $0 \%$ \\
\hline 4 & Sangat Kurang & 1 & $3 \%$ \\
\hline \multicolumn{2}{|r|}{ Jumlah } & 31 & $100 \%$ \\
\hline
\end{tabular}

Hal ini dapat ditarik kesimpulan bahwa pada umumnya peserta didik selalu aktif berdiskusi dalam proses pembelajaran.

7. Peserta didik menyanggah pendapat dengan baik ketika berdiskusi

\begin{tabular}{|c|c|c|c|}
\hline No & Jawaban Pernyataan & Frekuensi & persentase \\
\hline 1 & Selalu & 28 & $90,3 \%$ \\
\hline 2 & Sering & 1 & $3,2 \%$ \\
\hline 3 & Jarang & 2 & $6,5 \%$ \\
\hline 4 & Sangat kurang & 0 & $0 \%$ \\
\hline & Jumlah & 31 & $100 \%$ \\
\hline
\end{tabular}


Hal ini dapat ditarik kesimpulan bahwa pada umumnya peserta didik selalu menyanggah pendapat dengan baik ketika berdiskusi.

\section{Peserta didik menyampaikan gagasan atau pendapatnya}

\begin{tabular}{|c|c|c|c|}
\hline No & Jawaban Pernyataan & Frekuensi & Persentase \\
\hline 1 & Selalu & 28 & $90,3 \%$ \\
\hline 2 & Sering & - & - \\
\hline 3 & Jarang & 2 & $6,5 \%$ \\
\hline 4 & Sangat kurang & 1 & $3,2 \%$ \\
\hline \multicolumn{2}{|r|}{ Jumlah } & 31 & $100 \%$ \\
\hline
\end{tabular}

Hal ini dapat ditarik kesimpulan bahwa pada umumnya peserta didik selalu menyampaikan gagasan atau pendapatnya.

9. Peserta didik mengerjakan soal latihan yang diberikan oleh pendidik

\begin{tabular}{|c|c|c|c|}
\hline No & Jawaban Pernyataan & Frekuensi & Persentase \\
\hline 1 & Selalu & 27 & $87 \%$ \\
\hline 2 & Sering & 3 & $10 \%$ \\
\hline 3 & Jarang & 0 & $0 \%$ \\
\hline 4 & Sangat Kurang & 1 & $3 \%$ \\
\hline & Jumlah & 31 & $100 \%$ \\
\hline
\end{tabular}

Hal ini dapat ditarik kesimpulan bahwa pada umumnya peserta didik selalu mengerjakan soal latihan yang diberikan oleh pendidik.

10. Peserta didik senantiasa mengikuti setiap arahan yang diberikan oleh pendidik

\begin{tabular}{|c|c|c|c|}
\hline No & Jawaban Pernyataan & Frekuensi & Persentase \\
\hline 1 & Selalu & 31 & $100 \%$ \\
\hline 2 & Sering & - & - \\
\hline 3 & Jarang & - & - \\
\hline 4 & Sangat Kurang & - & - \\
\hline & Jumlah & 31 & $100 \%$ \\
\hline
\end{tabular}

Hal ini dapat ditarik kesimpulan bahwa pada umumnya peserta didik selalu senantiasa mengikuti setiap arahan yang diberikan oleh pendidik.

11. Peserta didik menjawab pertanyaan yang diberikan oleh pendidik, ketika sedang berlangsung tanya jawab.

\begin{tabular}{|c|c|c|c|}
\hline No & Jawaban Pernyataan & Frekuensi & Persentase \\
\hline 1 & Selalu & 28 & $90,3 \%$ \\
\hline 2 & Sering & 1 & $3,2 \%$ \\
\hline 3 & Jarang & 2 & $6,5 \%$ \\
\hline 4 & Sangat Kurang & - & - \\
\hline & Jumlah & 31 & $100 \%$ \\
\hline
\end{tabular}

Hal ini dapat ditarik kesimpulan bahwa pada umumnya peserta didik selalu menjawab pertanyaan yang diberikan oleh pendidik, ketika sedang berlangsung tanya jawab. 
12. Peserta didik dapat memecahkan atau menyelesaikan suatu tugas yang berhubungan dengan mata pelajaran Aqidah Akhlak.

\begin{tabular}{|c|c|c|c|}
\hline No & Jawaban Pernyataan & Frekuensi & Persentase \\
\hline 1 & Selalu & 28 & $90,3 \%$ \\
\hline 2 & Sering & - & - \\
\hline 3 & Jarang & 1 & $3,2 \%$ \\
\hline 4 & Sangat kurang & 2 & $6,5 \%$ \\
\hline & Jumlah & 31 & $100 \%$ \\
\hline
\end{tabular}

Hal ini dapat ditarik kesimpulan bahwa pada umumnya peserta didik selalu memecahkan atau menyelesaikan suatu tugas yang berhubungan dengan mata pelajaran Aqidah Akhlak.

13. Peserta didik mampu menjawab satu pertanyaa yang diberikan pendidik, dimana pertanyaan tersebut memiliki banyak jawaban yang masuk dalam kategori benar.

\begin{tabular}{|c|c|c|c|}
\hline No & Jawaban Pernyataan & Frekuensi & Persentase \\
\hline 1 & Selalu & 26 & $83,8 \%$ \\
\hline 2 & Sering & 1 & $3,2 \%$ \\
\hline 3 & Jarang & 2 & $6,5 \%$ \\
\hline 4 & Sangat kurang & 2 & $6,5 \%$ \\
\hline & Jumlah & 31 & $100 \%$ \\
\hline
\end{tabular}

Hal ini dapat ditarik kesimpulan bahwa pada umumnya peserta didik selalu mampu menjawab satu pertanyaan yang diberikan pendidik, dimana pertanyaan tersebut memiliki banyak jawaban yang masuk dalam kategori benar.

14. Peserta didik mendapat hukuman ketika tidak mengerjakan tugas atau tidak mematuhi aturan dalam proses pembelajaran.

\begin{tabular}{|c|c|c|c|}
\hline No & Jawaban Pernyataan & Frekuensi & Persentase \\
\hline 1 & Selalu & 22 & $71 \%$ \\
\hline 2 & Sering & 7 & $22,6 \%$ \\
\hline 3 & Jarang & 2 & $6,4 \%$ \\
\hline 4 & Sangat Kurang & - & - \\
\hline \multicolumn{2}{|r|}{ Jumlah } & 31 & $100 \%$ \\
\hline
\end{tabular}

Hal ini dapat ditarik kesimpulan bahwa pada umumnya peserta didik selalu mendapat hukuman ketika tidak mengerjakan tugas atau tidak mematuhi aturan dalam proses pembelajaran.

15. Peserta didik senantiasa mengangkat tangan ketika ingin bertanya.

\begin{tabular}{|c|c|c|c|}
\hline No & Jawaban Pernyataan & Frekuensi & Persentase \\
\hline 1 & Selalu & 28 & $90,3 \%$ \\
\hline 2 & Sering & 1 & $3,2 \%$ \\
\hline 3 & Jarang & 2 & $6,5 \%$ \\
\hline 4 & Sangat Kurang & - & - \\
\hline \multicolumn{2}{|r|}{ Jumlah } & 31 & $100 \%$ \\
\hline
\end{tabular}


Hal ini dapat ditarik kesimpulan bahwa pada umumnya peserta didik selalu senantiasa mengangkat tangan ketika ingin bertanya.

16. Peserta didik menyampaikan gagasan dan pendapatnya.

\begin{tabular}{|c|c|c|c|}
\hline No & Jawaban Pernyataan & Frekuensi & Persentase \\
\hline 1 & Selalu & 28 & $90,3 \%$ \\
\hline 2 & Sering & 1 & $3,2 \%$ \\
\hline 3 & Jarang & - & - \\
\hline 4 & Sangat kurang & 2 & $6,5 \%$ \\
\hline & Jumlah & 31 & $100 \%$ \\
\hline
\end{tabular}

Hal ini dapat ditarik kesimpulan bahwa pada umumnya peserta didik selalu menyampaikan gagasan dan pendapatnya.

17. Tidak melakukan pekerjaan lain yang akan menganggu proses belajar.

\begin{tabular}{|c|c|c|c|}
\hline No & Jawaban Pernyataan & Frekuensi & Persentase \\
\hline 1 & Selalu & 28 & $90,3 \%$ \\
\hline 2 & Sering & 1 & $3,2 \%$ \\
\hline 3 & Jarang & 2 & $6,5 \%$ \\
\hline 4 & Sangat Kurang & - & - \\
\hline & Jumlah & 31 & $100 \%$ \\
\hline
\end{tabular}

Hal ini dapat ditarik kesimpulan bahwa pada umumnya peserta didik tidak melakukan pekerjaan lain yang akan mengganggu proses belajar.

18. Memperbaiki jawaban teman yang salah.

\begin{tabular}{|c|c|c|c|}
\hline No & Jawaban Pernyataan & Frekuensi & Persentase \\
\hline 1 & Selalu & 27 & $87 \%$ \\
\hline 2 & Sering & 2 & $6,5 \%$ \\
\hline 3 & Jarang & 2 & $6,5 \%$ \\
\hline 4 & Sangat Kurang & - & - \\
\hline & Jumlah & 31 & $100 \%$ \\
\hline
\end{tabular}

Hal ini dapat ditarik kesimpulan bahwa pada umumnya peserta didik selalu memperbaiki jawaban teman yang salah.

19. Peserta didik senang metode yang digunakan pendidik dalam mengajar.

\begin{tabular}{|c|c|c|c|}
\hline No & Jawaban Pernyataan & Frekuensi & Persentase \\
\hline 1 & Selalu & 28 & $90,3 \%$ \\
\hline 2 & Sering & 1 & $3,2 \%$ \\
\hline 3 & Jarang & 2 & $6,5 \%$ \\
\hline 4 & Sangat Kurang & - & - \\
\hline & Jumlah & 31 & $100 \%$ \\
\hline
\end{tabular}

Hal ini dapat ditarik kesimpulan bahwa pada umumnya peserta didik selalu senang metode yang digunakan pendidik dalam mengajar. 
20. Peserta didik membuat rangkuman materi pembelajaran.

\begin{tabular}{|l|l|l|l|}
\hline No & Jawaban Pernyataan & Frekuensi & Persentase \\
\hline 1 & Selalu & 27 & $87 \%$ \\
\hline 2 & Sering & 3 & $10 \%$ \\
\hline 3 & Jarang & - & - \\
\hline 4 & Sangat Kurang & 1 & $3 \%$ \\
\hline Jumlah & 31 & $100 \%$ \\
\hline
\end{tabular}

Hal ini dapat ditarik kesimpulan bahwa pada umumnya peserta didik selalu membuat rangkuman materi pembelajaran.

21. Peserta didik termotivasi setelah menerima materi pembelajaran.

\begin{tabular}{|c|c|c|c|}
\hline No & Jawaban Pernyataan & Frekuensi & Persentase \\
\hline 1 & Selalu & 26 & $83,9 \%$ \\
\hline 2 & Sering & 3 & $9,6 \%$ \\
\hline 3 & Jarang & 2 & $6,5 \%$ \\
\hline 4 & Sangat Kurang & - & - \\
\hline & Jumlah & 31 & $100 \%$ \\
\hline
\end{tabular}

Hal ini dapat ditarik kesimpulan bahwa pada umumnya peserta didik selalu termotivasi setelah menerima materi pembelajaran.

22. Peserta didik mengaplikasikan pelajaran Aqidah Akhlak dikelas.

\begin{tabular}{|c|c|c|c|}
\hline No & Jawaban Pernyataan & Frekuensi & Persentase \\
\hline 1 & Selalu & 27 & $87 \%$ \\
\hline 2 & Sering & 3 & $10 \%$ \\
\hline 3 & Jarang & 0 & $0 \%$ \\
\hline 4 & Sangat Kurang & 1 & $3 \%$ \\
\hline \multicolumn{2}{|c|}{ Jumlah } & 31 & $100 \%$ \\
\hline
\end{tabular}

Hal ini dapat ditarik kesimpulan bahwa pada umumnya peserta didik selalu mengaplikasikan pelajaran Aqidah Akhlak.

\section{Analisis Data}

a. $\mathrm{R}=$ Range

$\mathrm{R}=\mathrm{H}-\mathrm{L}$

$\mathrm{R}=88-52$

$\mathrm{R}=36$

Jadi, rentang data adalah 36

b. $\mathrm{K}=$ Untuk mencari banyak kelas digunakan rumus,

$\mathrm{K}=1+3,3 \log \mathrm{N}$

$\mathrm{K}=1+3,3 \log 31$

$\mathrm{K}=1+3,3 \cdot 1,49$

$\mathrm{K}=5,9(6)$

Jadi banyak kelas 6

c. I = Panjang kelas interval untuk mencari kelas interval digunakan rumus, 


$$
\begin{aligned}
& I=\frac{R}{K} \\
& I=\frac{36}{6} \\
& I=6
\end{aligned}
$$

Setelah Range, jumlah kelas dan interval kelas diperoleh maka data di atas dibuat

\begin{tabular}{|c|c|c|c|c|c|c|}
\hline No & Interval & $\mathbf{X i}$ & $\mathbf{F i}$ & FiXi & $\mathbf{X i}^{2}$ & $\mathrm{FiXi}^{2}$ \\
\hline 1 & $52-57$ & 54,5 & 1 & 54,5 & 2970,3 & 2970,3 \\
\hline 2 & $58-63$ & 60,5 & 0 & 0 & 3660,3 & 0 \\
\hline 3 & $64-69$ & 66,5 & 0 & 0 & 4422,3 & 0 \\
\hline 4 & $70-75$ & 72,5 & 2 & 145 & 5256,3 & 10512,5 \\
\hline 5 & $76-81$ & 78,5 & 3 & 236 & 6162,3 & 18526 \\
\hline 6 & $82-88$ & 85 & 25 & 2125 & 7225 & 180625 \\
\hline \multicolumn{2}{|c|}{ Jumlah } & 417,5 & 31 & 2560,5 & 29696,5 & 212633,8 \\
\hline
\end{tabular}
menjadi berkelompok sepertai di bawah ini:

Tabel Berkelompok

Untuk mencari nilai rata-rata dengan membagi jumlah data dengan banyaknya data menggunakan rumus sebagai berikut:

Mencari

$\mathrm{M}=$ Mean ( jumlah observasi dibagi responden)

$\mathrm{M}=\frac{2613}{31}=84,3$

Mencari Standar Deviasi yang digunakan untuk menentukan bagaimana hasil observasi dalam sampel, dan berapa dekat titik data individu ke Mean atau rata-rata nilai sampel adapun rumusnya sebagai berikut:

$$
\begin{aligned}
& \mathrm{SD}=\sqrt{\frac{\sum \mathrm{fixi}^{2}-\frac{\left(\sum_{\mathrm{fixi}}{ }^{2}\right.}{\sum \mathrm{fi}}}{\sum \mathrm{fi}-1}} \\
& \mathrm{SD}=\sqrt{\frac{212633,8-\frac{(2560,5)^{2}}{31}}{31-1}} \\
& \mathrm{SD}=\sqrt{\frac{212633,8-\frac{6556160,3}{31}}{30}} \\
& \mathrm{SD}=\sqrt{\frac{212633,8-211489,04}{30}} \\
& \mathrm{SD}=\sqrt{\frac{1144,8}{30}} \\
& \mathrm{SD}=\sqrt{38,16} \\
& \mathrm{SD}=6,17
\end{aligned}
$$

Setelah mengetahui Mean dan Standar Deviasi langkah berikutnya adalah menjabarkan skor mentah dari ke 31 peserta didik tersebut ke dalam nilai A, B, C, dan D mengubah skor mentah ke dalam nilai standar skala lima: 
$M+1,5(\mathrm{SD})=84,3+1,5(6,17)=84,3+(9,25)=93,6 \longrightarrow$ Amat Baik
$M+0,5(\mathrm{SD})=84,3+0,5(6,17)=84,3+(3,08)=87,4 \longrightarrow$ Baik
$M-0,5(\mathrm{SD})=84,3-0,5(6,17)=84,3-(3,08)=81,2 \longrightarrow$ Cukup
$M-1,5(\mathrm{SD})=84,3-1,5(6,17)=84,3-(9,25)=75,1 \longrightarrow$ Kurang

Tabel Menentukan Interval

\begin{tabular}{|c|c|}
\hline Interval & Kriteria \\
\hline $81-100$ & Baik Sekali \\
\hline $61-80$ & Baik \\
\hline $41-60$ & Cukup \\
\hline $21-40$ & Buruk \\
\hline $0-20$ & Buruk Sekali \\
\hline
\end{tabular}

Hasil di atas menunjukkan bahwa perilaku belajar peserta didik pada mata pelajaran Aqidah Akhlak nilai rata-ratanya 84,3 yang berada pada interval 81-100 tergolong dalam kriteria Baik Sekali. Hal ini dapat dikatakan bahwa perilaku peserta didik dalam mengikuti mata pelajaran Aqidah Akhlak tergolong sangat baik.

\section{Deskripsi derajat hasil belajar Peserta Dididk pada Mata Pelajaran Aqidah Akhlak di Pesantren Al-Urwatul Wutsqaa Benteng Sidrap}

Berdasarkan penelitian yang telah dilakukan terhadap peserta didik kelas VIII Pesantren Al-Urwatul Wutsqaa Benteng Sidrap, pengukuran variabel tentang hasil belajar peserta didik pada mata pelajaran Aqidah Akhlak berhasil dikumpulkan dari 31 sampel dengan mengambil nilai MID. Dari nilai MID tersebut maka data tersebut akan diubah menjadi data bergolong. Utnuk mengubahnya menjadi data bergolong maka terlebih dahulu perlu dicari range, jumlah kelas, dan interval kelas setelah itu baru dianalisis.

a. $\mathrm{R}=$ Range

$\mathrm{R}=\mathrm{H}-\mathrm{L}$

$\mathrm{R}=80-70$

$\mathrm{R}=10$

Jadi, rentang data adalah 15

b. $\mathrm{K}=$ Untuk mencari banyak kelas digunakan Rumus:

$\mathrm{K}=1+3,3 \log \mathrm{N}$

$\mathrm{K}=1+3,3 \log 31$

$\mathrm{K}=1+3,3 \cdot 1,49$

$\mathrm{K}=5,92$

$\mathrm{K}=6$

Jadi, banyak kelas adalah 6

c. $\quad \mathrm{I}=$ Panjang kelas interval untuk mencari kelas interval digunakan Rumus:

$\mathrm{I}=\frac{\mathrm{R}}{\mathrm{K}}$

$\mathrm{I}=\frac{10}{6}$

$\mathrm{I}=1,6(2)$ 
Setelah Rage, Jumlah kelas dan interval kelas diperoleh, maka data diatas dibuat menjadi data bergolong seperti di bawah ini.

\section{Data Bergolong}

\begin{tabular}{|c|c|c|c|c|c|c|}
\hline No & Interval & $\mathbf{X i}$ & $\mathbf{F i}$ & $\mathbf{F i X i}$ & $\mathbf{X i}^{\mathbf{2}}$ & $\mathbf{F i X i}^{\mathbf{2}}$ \\
\hline 1 & $70-71$ & 70,5 & 21 & 1481 & 4970,3 & 104411 \\
\hline 2 & $72-73$ & 72,5 & 1 & 72,5 & 5256,3 & 5256,3 \\
\hline 3 & $74-75$ & 74,5 & 3 & 224 & 5550,3 & 16688 \\
\hline 4 & $76-77$ & 76,5 & 0 & 0 & 5852,3 & 0 \\
\hline 5 & $78-79$ & 78,5 & 2 & 157 & 6162,3 & 12325 \\
\hline 6 & 80 & 80 & 4 & 320 & 6400 & 25600 \\
\hline \multicolumn{2}{|c|}{ Jumlah } & $\mathbf{3 8 5 , 5}$ & $\mathbf{3 1}$ & $\mathbf{2 2 5 5}$ & $\mathbf{3 4 1 9 2}$ & $\mathbf{1 6 4 2 8 0 , 3}$ \\
\hline
\end{tabular}

Untuk mencari nilai rata-rata dengan membagi jumlah data dengan banyaknya data dengan menggunakan rumus sebagai berikut:

Mencari

$\mathrm{M}=$ Mean

$\mathrm{M}=\frac{\sum f x}{\sum x}$

$\mathrm{M}=\frac{2246}{31}=72,5$

Mencari standar deviasi yang digunakan untuk menentukan bagaimana sebaran data dalam sampel, dan berapa dekat titik data individu ke Meam atau rata-rata nilai sampel adapun rumusnya sebagai berikut:

$$
\begin{aligned}
& \mathrm{SD}=\sqrt{\frac{\sum f i x i^{2}-\frac{\left(\sum_{f i x i)^{2}}\right.}{\sum f i}}{\sum f i-1}} \\
& \mathrm{SD}=\sqrt{\frac{164280,3-\frac{(2255)^{2}}{31}}{31-1}} \\
& \mathrm{SD}=\sqrt{\frac{164280,3-\frac{5085025}{31}}{30}} \\
& \mathrm{SD}=\sqrt{\frac{164280,3-164033,1}{30}} \\
& \mathrm{SD}=\sqrt{\frac{247,2}{30}} \\
& \mathrm{SD}=\sqrt{8,24} \\
& \mathrm{SD}=2,9(3)
\end{aligned}
$$

Setelah mengetahui meam dan standar deviasi langka berikutnya adalah menyabarkan skor mentah dari ke 31 peserta didik tersebut kedalam nilai A, B, C, dan D. Mengubah Skor mentah kedalam skala lima:
$\mathrm{M}+1,5(\mathrm{SD})=72,5+1,5(3)=72,5+5=78$
$\longrightarrow \quad$ Amat Baik
$\mathrm{M}+0,5(\mathrm{SD})=72,5+0,5(3)=72,5+2=75$
Baik
$\mathrm{M}-0,5(\mathrm{SD})=72,5-0,5(3)=72,5-2=71$
Cukup 
$\mathrm{M}-1,5(\mathrm{SD})=72,5-1,5(3)=72,5-5=67 \quad \longrightarrow \quad$ Kurang

Menentukan Interval

\begin{tabular}{|c|c|}
\hline Interval & Kriteria \\
\hline $81-100$ & Baik Sekali \\
\hline $61-80$ & Baik \\
\hline $41-60$ & Cukup \\
\hline $21-40$ & Buruk \\
\hline $0-20$ & Buruk Seklai \\
\hline
\end{tabular}

Hasil di atas menunjukkan bahwa hasil belajar peserta didik pada mata pelajaran Aqidah Akhlak nilai rata-ratanya 72,5 yang berada pada interval 61-80 tergolong dalam kriteria Baik. Hal ini dapat dikatakn hasil belajar peserta didik dalam mengikuti mata pelajaran Aqidah Akhlak tergolong baik.

Hasil belajar merupakan pencapaian tujuan pendidikan pada peserta didik yang mengikuti proses belajar mengajar. Tujuan pendidikan bersifat ideal, sedang hasil belajar bersifat aktual. Hasil belajar merupakan realisasi tercapainya tujuan pendidikan, sehingga hasil belajar yang diukur sangat tergantung krpada tujuan pendidikannya.

Hasil belajar perlu dievaluasi. Evaluasi dimaksudkan sebagai hasil belajar cermin utnuk melihat kembali apakah tujuan yang ditetapkan telah tercapai dan apakah proses belajar mengajar telah berlangsung efektif untuk memperoleh hasil belajar.

\section{Hubungan antara Perilaku Belajar dengan Hasil Belajar Peserta Didik pada Mata Pelajaran Aqidah Akhlak di Pesantren Al-Urwatul Wutsqaa Benteng Sidrap}

Untuk mempermudah pengelolaan data diperlukan tabel penolong untuk menghitung kolerasi product moment sebagai berikut.

Tabel Penolong

\begin{tabular}{|c|c|c|c|c|c|}
\hline No Responden & $\mathbf{X}$ & $\mathbf{Y}$ & $\mathbf{X}^{\mathbf{2}}$ & $\mathbf{Y}^{\mathbf{2}}$ & $\mathbf{X Y}$ \\
\hline 1 & 88 & 70 & 7744 & 4900 & 6160 \\
\hline 2 & 88 & 70 & 7744 & 4900 & 6160 \\
\hline 3 & 88 & 70 & 7744 & 4900 & 6160 \\
\hline 4 & 80 & 71 & 6400 & 5041 & 5680 \\
\hline 5 & 77 & 70 & 5929 & 4900 & 5390 \\
\hline 6 & 88 & 70 & 7744 & 4900 & 6160 \\
\hline 7 & 88 & 70 & 7744 & 4900 & 6160 \\
\hline 8 & 88 & 70 & 7744 & 4900 & 6160 \\
\hline 9 & 52 & 71 & 2704 & 5041 & 3692 \\
\hline 10 & 88 & 70 & 7744 & 4900 & 6160 \\
\hline 11 & 76 & 75 & 5776 & 5625 & 5700 \\
\hline 12 & 87 & 75 & 7569 & 5625 & 6525 \\
\hline 13 & 88 & 78 & 7744 & 6084 & 6864 \\
\hline 14 & 88 & 70 & 7744 & 4900 & 6160 \\
\hline 15 & 82 & 75 & 6724 & 5625 & 6150 \\
\hline 16 & 88 & 70 & 7744 & 4900 & 6160 \\
\hline 17 & 88 & 70 & 7744 & 4900 & 6160 \\
\hline
\end{tabular}




\begin{tabular}{|c|c|c|c|c|c|}
\hline 18 & 88 & 70 & 7744 & 4900 & 6160 \\
\hline 19 & 88 & 78 & 7744 & 6084 & 6864 \\
\hline 20 & 88 & 80 & 7744 & 6400 & 7040 \\
\hline 21 & 72 & 70 & 5184 & 4900 & 5040 \\
\hline 22 & 88 & 70 & 7744 & 4900 & 6160 \\
\hline 23 & 88 & 70 & 7744 & 4900 & 6160 \\
\hline 24 & 71 & 70 & 5041 & 4900 & 4970 \\
\hline 25 & 88 & 70 & 7744 & 4900 & 6160 \\
\hline 26 & 84 & 70 & 7056 & 4900 & 5880 \\
\hline 27 & 88 & 80 & 7744 & 6400 & 7040 \\
\hline 28 & 84 & 73 & 7056 & 5329 & 6132 \\
\hline 29 & 88 & 80 & 7744 & 6400 & 7040 \\
\hline 30 & 88 & 70 & 7744 & 4900 & 6160 \\
\hline 31 & 88 & 80 & 7744 & 6400 & 7040 \\
\hline Jumlah & $\mathbf{2 6 1 3}$ & $\mathbf{2 2 4 6}$ & $\mathbf{2 2 2 0 6 3}$ & $\mathbf{1 6 3 1 5 4}$ & $\mathbf{1 8 9 4 4 7}$ \\
\hline
\end{tabular}

$$
\begin{aligned}
& \sum x=2613 \\
& \sum y=2246 \\
& \sum x^{2}=222063 \\
& \sum y^{2}=163154 \\
& \sum x y=189447 \\
& N=31
\end{aligned}
$$

Data dari tabel diatas kemudian dimasukkan kedalam rumus koefisien kolerasi product moment sebagai berikut:

$$
\begin{aligned}
& r x y=\frac{N \sum X Y-\left(\sum X\right) \cdot\left(\sum Y\right)}{\sqrt{\left[N \sum_{X} 2-\left(\sum X\right)^{2}\left[N \sum_{Y} 2-\left(\sum Y\right)^{2}\right]\right]}} \\
& r x y=\frac{31.189447-(2613) \cdot(2246)}{\sqrt{\left[31.222063-(2613)^{2}\left[31.163154-(2246)^{2}\right]\right]}} \\
& r x y=\frac{5872857-5868798}{\sqrt{[6883953-6827769] \cdot[5057774-5044516]}} \\
& r x y=\frac{4059}{\sqrt{[56184][13258]}} \\
& r x y=\frac{4059}{\sqrt{744887472}} \\
& r x y=\frac{4059}{27292,6} \\
& r x y=0,15
\end{aligned}
$$

Untuk dapat mengetahui hubungan terhadap koefisien korelasi yang ditemukan besar atau kecil antara perilaku belajar dengan hasil belajar peserta didik, maka dapat berpedoman pada tabel sebagai berikut: 
Pedoman Untuk Mmeberikan Interpretasi

Koefisien Kolerasi

\begin{tabular}{|c|c|}
\hline Interval Koefisien & Tingkat Hubungan \\
\hline $0,00-0,199$ & Sangat rendah \\
$0,20-0,399$ & Rendah \\
$0,40-0,599$ & Sedang \\
$0,60-0,799$ & Kuat \\
$0,80-1,000$ & Sangat kuat \\
\hline
\end{tabular}

Dari tabel diatas terlihat tidak ada hubungan yang kuat antara perilaku belajar dengan hasil belajar peserta didik sebesar 0,15.

Selanjutnya menguji signifikansi dengan bebrapa langkah-langkah berikut:

$\alpha=0,05=5 \%$

$\frac{0,05}{2}=0,025$

$\mathrm{db}=\mathrm{n}-2$

$=31-2=29$

Jadi $t_{0}$ ialah $0,025(29)=0,725$

Dengan derajat kebebasan 29 maka diperoleh $\mathrm{t}_{\text {tabel }}$ pada taraf signifikasi $5 \%$ sebesar 1,699 .

Selanjutnya menentukan nilai uji t dengan menggunakan rumus:

$$
\begin{aligned}
& \mathrm{t}_{0}=r \sqrt{\frac{r-2}{1-r^{2}}} \\
& =0,15 \sqrt{\frac{31-2}{1-(0,15)^{2}}} \\
& =0,15 \sqrt{\frac{29}{1-0,0225}} \\
& =0,15 \sqrt{\frac{29}{0,98}} \\
& =0,15 \sqrt{29,6} \\
& =0,15 \times 5,4 \\
& =0,81
\end{aligned}
$$

Ho diterima jika $t$ hitung $<\mathrm{t}$ tabel

$\mathrm{H}_{\mathrm{O}}$ ditolak jika $\mathrm{t}$ hitungnya $>\mathrm{t}$ tabel

Dengan melakukan pengujian secara signifikansi maka dapat disimpulkan bahwa t hitung $\left(\mathrm{t}_{0}\right)=0,81<$ dari $\mathrm{t}$ tabel $=1$,699. Jadi $\mathrm{H}_{\mathrm{O}}$ diterima dan $\mathrm{H}_{\mathrm{a}}$ ditolak, artinya tidak terdapat hubungan antara perilaku belajar dengan hasil belajar peserta didik pada mata pelajaran aqidah akhlak di pesantren al-urwatu wutsqaa benteng sidrap.

Adapun kesimpulan yang dapat diambil dari hasil pengujian hipotesis diatas bahwa hipotesis diterima. Rata-rata perilaku belajar peserta didik pada mata pelajaran Aqidah Akhlak 84,3 terletak pada interval 81-100, yang berada pada kategori Baik Sekali,sedangkan skor rata-rata Hasil Belajar peserta didik adalah 72,5 yang terletak pada 
interval 61-80, yang berada pada kategori baik. Sedangkan hasil analisis data pada korelasi product moment untuk mencari hubungan antara perilaku belajar dengan hasil belajar pada mata pelajaran aqidah akhlak diperoleh nilai 0,15 yang terletak pada interval koefisien 0,00-0,199, yang tidak memiliki tingkat hubungan antara keduanya yaitu Sangat Rendah. Hasil uji t menunjukkan bahwa $\mathrm{t}_{0}=0,81<$ dari $\mathrm{t}_{\mathrm{t}}=1,699$. Jadi dapat dikatakan bahwa $\mathrm{H}_{\mathrm{O}}$ diterimah dan $\mathrm{H}_{\mathrm{a}}$ ditolak, artinya tidak terdapat hubungan antara perilaku belajar dengan hasil belajar peserta didik pada mata pelajaran Aqidah Akhlak di Pesantren Al-Urwatul Wutsqaa Benteng Sidrap.

\section{PEMBAHASAN}

Perilaku belajar adalah suatu hal yang mendasar yang dimiliki oleh peserta didik dimana hal tersebut mencerminkan kelakuan, perbuatan, etika, atau tingakah laku oleh peserta didik ketika mengikuti suatu proses pembelajaran. Perilaku belajar peserta didik pada mata pelajaran Aqidah Akhlak menunjukkan nilai rata-ratanya 84,3 yang berada pada interval 81-100 tergolong dalam kriteria Baik Sekali. Hal ini dapat dikatakan bahwa perilakau peserta didik dalam mengikuti mata pelajaran Aqidah Akhlak tergolong Sangat Baik. Hal itu dapat dilihat pada kemampuan peserta didik dalam memahami kemudian mengaplikasikannya dalam kehidupan sehari-hari.

Hasil belajar merupakan pencapaian tujuan pendidikan pada peserta didik yang mengikuti proses belajar mengajar. Hasil belajar peserta didik pada mata pelajaran Aqidah Akhlak nilai rata-ratanya 72,5 yang berada pada interval 61-80 tergolong dalam kriteria Baik. Hal ini dapat dikatakan hasil belajar peserta didik dalam mengikuti mata pelajaran Aqidah Akhlak tergolong Baik. Hal itu dapat dikatakan karena peserta didik mampu menyerap dan memahami pelajaran Aqidah Akhlak yang diberikan pendidik.

Adapun hubungan hubungan antara perilaku belajar dengan hasil belajar peserta didik pada mata pelajaran Aqidah Akhlak di Pesantren Al-Urwatul Wutsqaa Benteng Sidrap memiliki tingkat korelasi 0,15 yang berada pada interval 0,00-0,199 dengan tingkat hubungan Sangat Rendah. Adapun hasil uji t diperoleh $t_{0}=0,81$ dan $t_{t}=1,69$. Dari hasil hipotesis dapat dikatakan bahwa $\mathrm{H}_{0}$ diterima dan $\mathrm{H}_{\mathrm{a}}$ ditolak. Hal itu dapat dilihat dari hasil uji hipotesis yang menunjukkan bahwa $\mathrm{t}_{0}=0,81<\mathrm{t}_{\mathrm{t}}=1,699$ yaitu tidak terdapat hubungan antara perilaku belajar peserta didik terhadap hasil belajar pada mata pelajaran Aqidah Akhlak di Pesantren Al-Urwatul Wutsqaa Benteng Sidrap.

Adapun faktor-faktor yang mempengaruhi tidak adanya hubungan antara perilaku belajar dengan hasil belajar peserta didik pada mata pelajaran Aqidah Akhlak di Pesantren Al-Urwatul Wutsqaa Benteng Sidrap, berdasarkan hasil observasi yaitu : tidak semua perilaku belajar peserta didik yang mempunyai perilaku belajar yang baik memiliki hasil belajar yang baik pula, peserta didik mempunyai daya tangkap yang berbeda-beda misalnya terkadang ada peserta didik yang mengerti tapi belum memahami, terkadang ada peserta didik yang mengerti sesaat, adapula peserta didik yang mengerti dan 
memahami jika melakukan praktek dan penggunaan metode dalam pembelajaran Aqidah Akhlak yang dipilih oleh pendidik.

\section{DAFTAR PUSTAKA}

Ahmadi Abu dan Widono Supriyono, Psikologi Belajar, Jakarta: Rineka Cipta, 1991.

Arikunto Suharsimi, Prosedur Penelitian suatu Pendekatan Praktik, Jakarta: PT. Rineka Cipta, 1996.

Azwar Saifuddin, (Sikap Manusia) Teori dan Pengukurannya, Yogyakarta: Pustaka Pelajar Offset, 2005.

Anas Sudijono, Pengantar Statistik Pendidikan, Jakatra: PT. Raja Wali Press, 1957.

Damopolii Muljono, Pedoman Penulisan Karya Tulis Ilmiah, Makassar: Alauddin Pers, 2013.

Departemen Pendidikan Nasional RI UUD NO. 20, Jakarta: Biro Hukum dan Sekretariat Jendral Departemen Pendidikan Nasional, 2003.

Hasbullah, Dasar-Dasar Ilmu Pendidikan, Jakarta: PT. Raja Grafindo Persada, 2012.

Jhon M, echol, et al, Kamus Inggris Indonesia, Jakarta: PT. Gramedia, 1996.

Kusyairi Umy, Psikologi, Makassar: Alauddin University Press, 2014.

Muhaimin, Wacana Pengembangan Pendidikan Islam, Yogyakarta: Pustaka Pelajar, 2003.

Proyek Pembinaan Perguruan Tinggi Agama, Ilmu Pendidikan Islam, Jakarta: Perpustakaan Pusat IAIN, 1984.

Purwanto, Evaluasi Hasil Belajar, Yogyakarta: Celeban Timur UH III/548, 2011.

Ratna Yudhawati, dkk. Teori-teori psikologi Pendidikan, Jakarta: PT Prestasi Pustakaraya, 2011.

Sabiq Sayid, Aqidah Islam Pola Hidup Manusia Beriman, Bandung: C.V Diponegoro, 1978.

Sanjaya Wina, Kurikulum dan Pembelajaran, Jakarta: Kencana, 2008.

Slameto, Belajar dan Faktor-Faktor yang Mempengaruhinya, Jakarta: Rineka Cipta, 1995.

Sudjana Nana, Penelitian Hasil Proses Belajar Mengajar, Bandung: Rosda Karya, 2005.

Sugiyono, Metode Penelitian Pendidikan (Pendekatan Kuantitatif, Kualitatif, dan $R$ \& D), Bandung: Alfabeta, 2014. 
Syah Muhibbin, Psikologi Pendidikan Dengan Pendekatan Baru, Bandung: Remaja Rosda Offset, 2000.

Wahyuddin Dinn, dkk, Pengantar Psikologi Umum, Surabaya: Sinar Wijaya, 1991.

Yudhawati Ratna, dkk, Teori-Teori Psikologi Pendidikan, Jakarta: PT. Prestasi Pustaka Raya, 2011.

Zuhairini, Filsafat Pendidikan Islam, Jakarta: Bumi Aksara, 1995. 